\title{
THE ANALYZING OF AMBIGUITY ON STUDENTS' WRITING MADE BY STUDENTS IN SMK DHARMA BAKTI MEDAN
}

\author{
Elya Batu Baren, Fiber Yun A. Ginting, Karisma E. Tarigan \\ Catholic University of Saint Thomas \\ Email : karisma_tarigan@ust.ac.id
}

\begin{abstract}
The aims of this study were to figure out the casual factors of ambiguity found in students writing. The subject of this study was the students of Class XI-TKR of SMK Dharma Bakti Medan. The research design was in the form of descriptive qualitative research. The instrument of collecting data was the students' sheet of English writing text. In conclusion, the most dominant ambiguity in lexical meaning found in writing text by Class XI-TKR of SMK Dharma Bakti Medan was polysemy ambiguity. There were 10 casual factors of why ambiguity found in students' writing text based on the analysis of the structure of sentence in students' English writing. The most reasons were: (1) the students did not give the specific details in their writing, usually they preferred the short writing, (2) there were several vocabularies which could be reasonably interpreted more than one way or reasonably interpreted more than one thing, (3) the students felt confused to find appropriate vocabularies to express the meaning. As a result, they sometimes left the sentence undone or hanged without a clear idea, due to the lack of vocabularies. The analysis of ambiguity in lexical meaning that made by students of Class XI-TKR of SMK Dharma Bakti Medan revealed that students should learn semantic as the main subject in English writing to understand multiplicity of meanings.
\end{abstract}

Keywords: ambiguity, lexical, and writing

\section{Introduction}

Nowadays, there are many ways to communicate with the other due to the developments of technology. There are many media, whether electronic or printed media to share information and to keep in touch with the other. People can get information about the development of the world and everything happens in a day from electronic and printed media. As a mean of communication, language holds an important role in life. As social creature, people need language to communicate and interact with the other to fulfill their needs. People create language by forming words which have meaning and can be understood to all people. People can express their ideas, share information and feelings directly or indirectly, in a form of spoken or written by using language.

A sentence is said to be ambiguous whenever it can be associated with two or more different meaning. As Heredia and Cieslicka (2020:96) state ambiguity is prevalent across all levels of language processing. On the semantic level, all language includes lexical items, both written and spoken, that have more than one meaning. The ambiguity of a words or phrase that more than one meaning stands in a sentence can be seen from the examples below:

1) However, let's be clear.

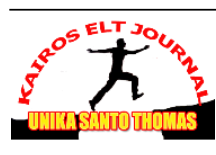


The word of clear has two possible meanings. The first, the word of clear can be obvious or clean. And the second, it can be empty. Therefore, the meaning of clear can be obvious or empty.

2) Put the block in the box on the table.

This sentence has more than one meaning. It can be put the block (in the box on the table) or it can be put (the block in the box) on the table.

From the statement above, it can be concluded that the level of ambiguity was showed in semantic level. The semantic level of ambiguity that includes lexical item and the second, the phonology level of ambiguity. Lexical ambiguity arises when a single word has more than one meaning.

\section{Review of Literature}

Semantic Theory

Studying a language could not be separated from studying the meaning of that language because when one was learning language, he/she was also learning the meaning of the language. The meaning of a language could be seen from its relation between words, i.e. the sense of one word is related to the sense of another. According to Geisler (2012:3) "Sense relation is any relation between lexical units within a semantic system of a language. The kinds of sense relation are paraphrase or synonymy, entailment, presupposition, contradiction, tautology, inconsistency, anomaly, and ambiguity." Based on the statement, one kind of sense relation was ambiguity and it was a part of semantic.

Adams and Cramer (2014:75) stated that sometimes you can resolve the ambiguity by looking at the symbol or word in relation to the rest of the sentence or in the relation to other words or provisions in the documents. Aurum and Wohlin (2006:248) believed that ambiguous happens if it has multiple interpretations despite the reader's knowledge of the context. It does not matter whether the author unintentionally introduced the ambiguity, but knows what was meant, he or she intentionally introduced the ambiguity to include all possible interpretations.

\section{Lexical Ambiguity}

Hong (2014:10) explained that lexical ambiguity is a linguistic term for a word's capacity to carry two or more obviously different meanings, for example, bank. The word bank has several distinct lexical definitions, including "financial institution" and "edge of a river." The context in which a lexically ambiguous word is used often makes evident which of the meanings is intended. Therefore, if someone uses a multi-defined word, it is sometimes necessary to clarify the context by elaborating on the specific intended meaning. Lexical ambiguity arises when a word or concept has an inherently diffuse meaning based on widespread or informal usage. This is often the case, for example, with idiomatic expressions, whose definitions are rarely if ever well-defined and are presented in the context of a larger argument that invites a conclusion. Strazny (2013:40) stated that lexical ambiguity can be either 'polysemy' or 'homonymy'. Homonymys are distinct units in the vocabulary with identical pronunciation (homophones) and/or spelling (homographs).

\section{Homophone}


Sarkar (2016:26) defined that homophones are words that have the same pronunciation but different meanings and they can have the same or different feelings. Examples would be the words pair (meaning couple) and pear (the fruit). They sound the same but have different meanings. Carley and Mess (2020:3) argued that words with different meanings are spelled completely different but are pronounced in the same way. Such words are called homophones. Examples of homophones are wait/weight, know/no, sea/see, cite/sight/site.

\section{Homograph}

Sarkar (2016:26) stated that homographs are words that have the same written form or spelling but have different meanings. Some examples of homographs include, the word lead as in I am using a lead pencil and Please lead the soldier to the camp, and also the word bass in Turn up the bass for the song and I just caught a bass today while I was out fishing. The spelling stays the same but the pronunciation changes based on the context in the sentences. According to Chu (2003:53) "Homographs are terms spelled the same but carrying different meanings in different contexts. Terms such as record, subject, drug, spring, bank, and duty are just a few examples of homographs. In natural language representation and retrieval, homographs can produce problems such as ambiguity, due to the lack of context, for example, duty (responsibility) and duty (tax)."

\section{Polysemy}

Sarkar (2016:26) stated that polysemes are words that have the same written form or spelling and different but very relatable meanings. While this is very similar to homonymy, the difference is subjective and depends on the context, since these words are relatable to each other. A good example is the word bank which can mean (1) financial institution, (2) the bank of the river, (3) the building that belongs to the financial institution, or (4) a verb meaning to rely upon. These examples use the same word bank and are homonyms. But only (1), (3), and (4) are polysemes representing a common theme (the financial organization representing trust and security). Botha, et. al. (2013:140) asserted that polysemy implies a word with many senses. It is the use of the same word in two or more distinct meanings. Deane (2011:89) explained that polysemy presents a number of challenges to traditional semantic theories. (i) There is the problem of sense selection. Given that a word can mean two different things, how do we know when it will mean what?, (ii) There is the problem of semantic relatedness. Polysemy is distinct from homonymy because the senses of a polysemous word are related to one another. What kinds of relations are these? How can we recognize their presence?, (iii) There is the problem of category identity. It is often hard to tell whether the senses of a polysemous word should be viewed as distinct (but related) categories, or whether they should be viewed as contextual variants of a single underlying category. Based on the statements, polysemy refers to the situation where a word has two or more distinct meanings, but those are still related in sense.

\section{Writing}

Mishra (2007:126) stated that writing can also be seen as the skill of communicating with either the 'now' audience/readers or 'later' audience/readers through the medium of paper/screen/display. The effectiveness of writing depends 
on clarity of expression and a style that is appropriate and unambiguous. Every act of writing is seen as an act of reading and reading itself is a kind of writing. From one perspective, writing is the way in which we evaluate or express reading skill and reading is the way in which we evaluate writing skill. The close relationship between writing and thinking on one hand and writing and reading on the other hand makes writing a valuable part of any language learning and skill-acquiring programme. All effective writers avoid ambiguity. This can be ensured if you are careful about the word order.

Moreover, Mishra (2007:126) stated that the characteristic of effective writing:

1. Purpose : The reason for writing

2. Audience : The readers

3. Writer's process : Getting ideas, getting started, writing drafts, revising

4. Mechanics : Handwriting, spelling, punctuation

5. Grammar : Rules of verb, agreement, articles

6. Syntax: Sentence structure, stylistic choice

7. Content : Relevance, clarity, originality, logic

8. Word choice : Vocabulary, idioms, tone

\section{Research Methodology}

The research design of this study was descriptive qualitative research. The writer used this method to analyze the students' ability in finding ambiguity in a short paragraph. In this study, the writer collected the data from a paper test of students' writing and analyzed the data inductively, as Merriam and Grenier (2019:7) mentioned that an interpretive and descriptive qualitative study exemplifies all the characteristics of qualitative research, that is, the researchers is first and foremost interested in understanding how participants make meaning of a situation or phenomenon. The subject of this research was on the first grade SMK Dharma Bakti Medan. There are two parallel classes and each class consists of 40 students. The writer selected one class from two classes parallel. It is Class A. It is because the limitation time and each of classes consist of same student's qualification. In collecting the data, the instrument used in this study are human instrument and writing test result. The writer collected the students' writing test paper to be documented and read carefully. After collecting the data, the next step was data must be classified and analyzed. After collecting the data from students, the writer analyzing the data as follow:

1. Identify the ambiguity which is found on every words that contain in phrase or sentence.

2. Classify the data into the sub category of ambiguity.

3. Interpret and describe the data which have been classified.

4. Analyze the data to infer the cause and source they made.

\section{Discussion}

There were several factors why ambiguity found in students' writing text based on the analysis of the structure of sentence in students' English writing as follows:

1. The students did not give the specific details in their writing, usually they preferred the short writing.

2. There were several vocabularies which could be reasonably interpreted more than one way or reasonably interpreted more than one thing. 
3. The students felt confused to find appropriate vocabularies to express the meaning. As a result, they sometimes left the sentence undone or hanged without a clear idea, due to the lack of vocabularies.

4. The students did not attach the context of text, and generally there were two until three sentences that did not follow the idea or the purpose in the title of English writing.

5. The students used the same word in the same sentence twice.

6. The students had a problem in phonological writing when they were given a text from listening comprehension test.

7. Students did not want to find the synonym in the word to avoid ambiguity.

8. The students inclined to use translation as a main guide to write an English paragraph, so the structure of their English generally reversed or wrongly placed in their English writing and caused ambiguity.

9. The students did not emphasize the point of words that they used, so that the concept of the sentence in their writing text was not clear.

10. The students did not check for the sense, meaning, and clarity in their writing text once their English writings were finished.

The calculation of ambiguity in lexical meaning were described as follows:

Table 1 The Calculation of Ambiguity in Lexical Meaning

\begin{tabular}{|c|c|c|c|c|}
\hline No. & $\begin{array}{l}\text { Types of } \\
\text { Ambiguity } \\
\text { in Lexical } \\
\text { Meaning }\end{array}$ & $\begin{array}{c}\text { Word of } \\
\text { Ambiguity }\end{array}$ & $\begin{array}{c}\text { Definition of Ambiguity } \\
\text { Word }\end{array}$ & $\begin{array}{l}\text { Frequency } \\
\quad \text { and } \\
\text { Percentage }\end{array}$ \\
\hline \multirow[t]{5}{*}{1.} & \multirow[t]{5}{*}{ omophones } & $\begin{array}{l}\text { Breath } \\
\text { Breadth }\end{array}$ & $\begin{array}{l}\text { Amount of air that enters the } \\
\text { lungs at one time. } \\
\text { Distance from side to side, } \\
\text { Width. }\end{array}$ & \multirow[b]{5}{*}{$\begin{array}{l}10 \\
(23.25 \%)\end{array}$} \\
\hline & & Stuck & $\begin{array}{l}\text { Became fixed in one } \\
\text { position }\end{array}$ & \\
\hline & & & Quality of voice. & \\
\hline & & Ton & $\begin{array}{l}\text { Damaged something by } \\
\text { pulling it apart or into } \\
\text { pieces. }\end{array}$ & \\
\hline & & Break & $\begin{array}{l}\text { Stopped doing something } \\
\text { from a while. } \\
\text { Device for reducing the } \\
\text { speed of or stopping a } \\
\text { vehicle. }\end{array}$ & \\
\hline
\end{tabular}




\begin{tabular}{|c|c|c|c|c|}
\hline No. & $\begin{array}{l}\text { Types of } \\
\text { Ambiguity } \\
\text { in Lexical } \\
\text { Meaning }\end{array}$ & $\begin{array}{c}\text { Word of } \\
\text { Ambiguity }\end{array}$ & $\begin{array}{c}\text { Definition of Ambiguity } \\
\text { Word }\end{array}$ & $\begin{array}{l}\text { Frequency } \\
\quad \text { and } \\
\text { Percentage }\end{array}$ \\
\hline & & $\begin{array}{l}\text { Wash } \\
\text { Was }\end{array}$ & $\begin{array}{l}\text { Made something or } \\
\text { somebody clean using water } \\
\text { and soap. } \\
\text { The form of Be. }\end{array}$ & \\
\hline \multirow[t]{7}{*}{2.} & \multirow[t]{2}{*}{ omographs } & $\begin{array}{l}\text { Hard } \\
\text { Hard }\end{array}$ & $\begin{array}{l}\text { Needing or showing a great } \\
\text { effort. } \\
\text { Firm and solid, not easy } \\
\text { to bend or cut. }\end{array}$ & \\
\hline & & Rest & $\begin{array}{l}\text { The remaining part of } \\
\text { something. } \\
\text { The period of relaxing or } \\
\text { sleeping, Did nothing. }\end{array}$ & \\
\hline & & Couple & $\begin{array}{l}\text { Fasten or join two parts of } \\
\text { something } \\
\text { Two people or things seen } \\
\text { together or associated. }\end{array}$ & \multirow[t]{5}{*}{$\begin{array}{l}14 \\
(32.55 \%)\end{array}$} \\
\hline & & Miss & $\begin{array}{l}\text { Felt sad because of the } \\
\text { absence of something. } \\
\text { Passed over, not taking part } \\
\text { of somebody or something. }\end{array}$ & \\
\hline & & Smooth & $\begin{array}{l}\text { Happening or continuing } \\
\text { without any problems. } \\
\text { Completely flat and } \\
\text { without any lumps or holes } \\
\text { (skin). }\end{array}$ & \\
\hline & & Miss & $\begin{array}{l}\text { Could not be found or lost. } \\
\text { Felt sad because of the } \\
\text { absence of something. }\end{array}$ & \\
\hline & & Spotlight & $\begin{array}{l}\text { Direct attention at a problem } \\
\text { or situation. } \\
\text { Lamp used for sending } \\
\text { a strong light directly. }\end{array}$ & \\
\hline
\end{tabular}




\begin{tabular}{|c|c|c|c|c|}
\hline No. & $\begin{array}{l}\text { Types of } \\
\text { Ambiguity } \\
\text { in Lexical } \\
\text { Meaning }\end{array}$ & $\begin{array}{c}\text { Word of } \\
\text { Ambiguity }\end{array}$ & $\begin{array}{c}\text { Definition of Ambiguity } \\
\text { Word }\end{array}$ & $\begin{array}{l}\text { Frequency } \\
\quad \text { and } \\
\text { Percentage }\end{array}$ \\
\hline \multirow[t]{14}{*}{3.} & \multirow[t]{6}{*}{ olysemy } & Mild & $\begin{array}{l}\text { Not strong or bitter. } \\
\text { Gentle or kind, not violent. }\end{array}$ & \multirow{6}{*}{$\begin{array}{l}19 \\
(44,18 \%)\end{array}$} \\
\hline & & Runny & $\begin{array}{l}\text { Producing liquid (of the eyes } \\
\text { or nose). Liquid. }\end{array}$ & \\
\hline & & Sore & $\begin{array}{l}\text { Painful (because of } \\
\text { infection). }\end{array}$ & \\
\hline & & Sore & \multirow{2}{*}{$\begin{array}{l}\text { Upset and angry. } \\
\text { Very bad, intense, or } \\
\text { difficult. Patience. }\end{array}$} & \\
\hline & & Severe & & \\
\hline & & Date & $\begin{array}{l}\text { With all the latest } \\
\text { information. }\end{array}$ & \\
\hline & & Date & $\begin{array}{l}\text { Boyfriend or girlfriend } \\
\text { arrangement to meet. } \\
\text { Particular day of the month } \\
\text { or year. }\end{array}$ & \\
\hline & & Monster & $\begin{array}{l}\text { A large, ugly, frightening } \\
\text { creature. }\end{array}$ & \\
\hline & & Monster & A cruel or evil. & \\
\hline & & Hit & $\begin{array}{l}\text { To have a sudden, usually } \\
\text { bad effect for person, thing, } \\
\text { or place. } \\
\text { To strike somebody or } \\
\text { something with hand. }\end{array}$ & \\
\hline & & Sweep & $\begin{array}{l}\text { Moved over or along, in } \\
\text { order to attack something or } \\
\text { somebody. }\end{array}$ & \\
\hline & & Sweep & $\begin{array}{l}\text { Removed dust, dirt, etc with } \\
\text { brush. }\end{array}$ & \\
\hline & & Mask & $\begin{array}{l}\text { Covering to hide } \\
\text { someone's face. }\end{array}$ & \\
\hline & & Mask & $\begin{array}{l}\text { Covering face } \\
\text { protection. }\end{array}$ & \\
\hline
\end{tabular}




\begin{tabular}{|l|l|c|c|c|}
\hline No. & $\begin{array}{l}\text { Types of } \\
\text { Ambiguity } \\
\text { in Lexical } \\
\text { Meaning }\end{array}$ & $\begin{array}{c}\text { Word of } \\
\text { Ambiguity }\end{array}$ & $\begin{array}{c}\text { Definition of Ambiguity } \\
\text { Word }\end{array}$ & $\begin{array}{c}\text { Frequency } \\
\text { and } \\
\text { Percentage }\end{array}$ \\
\hline $\begin{array}{l}\text { Total of } \\
\text { Ambiguity in } \\
\text { Lexical Meaning }\end{array}$ & & & \\
\hline
\end{tabular}

There were 10 factors of why ambiguity found in students' writing text based on the analysis of the structure of sentence in students' English writing as follows: (1) the students did not give the specific details in their writing, usually they preferred the short writing, (2) there were several vocabularies which could be reasonably interpreted more than one way or reasonably interpreted more than one thing, (3) the students felt confused to find appropriate vocabularies to express the meaning. As a result, they sometimes left the sentence undone or hanged without a clear idea, due to the lack of vocabularies, (4) the students did not attach the context of text, and generally there were two until three sentences that did not follow the idea or the purpose in the title of English writing, (5) the students used the same word in the same sentence twice, (6) the students had a problem in phonological writing when they were given a text from listening comprehension test, (7) students did not want to find the synonym in the word to avoid ambiguity, (8) the students inclined to use translation as a main guide to write an English paragraph, so the structure of their English generally reversed or wrongly placed in their English writing and caused ambiguity, (9) the students did not emphasize the point of words that they used, so that the concept of the sentence in their writing text was not clear, and (10) the students did not check for the sense, meaning, and clarity in their writing text once their English writings were finished.

\section{Conclusion}

Based on the data analysis, the conclusion to answer the research problem presented as follows: the research problem about the casual factors of ambiguity in students English writing, the writer found 10 factors that cause ambiguity as follows: (1) the students did not give the specific details in their writing, usually they preferred the short writing, (2) there were several vocabularies which could be reasonably interpreted more than one way or reasonably interpreted more than one thing, (3) the students felt confused to find appropriate vocabularies to express the meaning. As a result, they sometimes left the sentence undone or hanged without a clear idea, due to the lack of vocabularies, (4) the students did not attach the context of text, and generally there were two until three sentences that did not follow the idea or the purpose in the title of English writing, (5) the students used the same word in the same sentence twice, (6) the students had a problem in phonological writing when they were given a text from listening comprehension test, (7) students did not want to find the synonym in the word to avoid ambiguity, (8) the students inclined to use translation as a main guide to write an English paragraph, so the structure of their English generally reversed or wrongly placed in their English writing and caused ambiguity, (9) the students did not emphasize the point of words that they used, so that the concept of the sentence in their writing 
text was not clear, and (10) the students did not check for the sense, meaning, and clarity in their writing text once their English writings were finished.

\section{Suggestion}

Based on the problem statement and after having data analysis, the writer suggested for:

1. The words, the phrases, or the sentences in English possibly had more than one meaning that named ambiguity. So that the teacher should carefully use the word, the phrase, or the sentence and choose the suitable word, phrase, or sentence according to the meaning. It was hoped that any kind of ambiguities could be solved by finding a coherence in a text.

2. For the students who study Semantic, in the case of ambiguity, they could take the result of this research as a reference. Students should fully aware about the topic and the context of situation in paragraph to figure out the right interpretation and the exact meaning of the words in sentences.

For other researchers, they could also take this research as a reference for further research in the case of ambiguity. They could combine and develop the research with many interdisciplinary studies.

\section{BIBLIOGRAPHY}

Adams, C. M. \& Cramer, P. K. 2014. Drafting Contracts in Legal English: Crossborder Agreement Governed by US Law. New York: Walter Kluwer Law and Business. Aurum,

A. \& Wohlin, C. 2006. Engineering and Managing Software Requirements. Berlin: Springer.

Botha, W., Mavoungou, P. \& Nikomo, D. 2013. Festschrift Rufus H Gouws. Stellenbosch: Sun Press.

Carley, P. \& Mess, I. 2020. American English Phonetics and Pronunciation Practice. Oxon: Routledge Taylor and Francis Group.

Chu, H. 2003. Information Representation and Retrieval in the Digital Age. New Jersey: Information Today, Inc.

Deane, P. D. 2011. Grammar in Mind and Brain: Explorations in Cognitive Syntax. Berlin: Mouton de Gruyter.

Geisler, H. 2012. Sense Relations: Identity. Stockholm: Grin.

Heredia, R. \& Cieslicka, B. 2020. Bilingual Lexical Ambiguity Resolution. Cambridge Cambridge University Press.

Hong, J. 2014. Verb Sense Discovery in Mandarin Chinese - A Corpus based Knowledge- Intensive Approach. New York: Springer. 
Merriam, S.B. \& Grenier, R.S. 2019. Qualitative Research in Practice: Examples forDiscussion and Analysis. San Fransisco: John Wiley and Sons.

Mishra. 2007. Communication Skills for Engineers. Chennai: Pearson Education.

Sarkar, D. 2016. Text Analytics with Python: A Practical Real-World Approach to GainingActionable Insights from Your Data. Karnataka: Apress.

Strazny, P. 2013. Encyclopedia of Linguistics. New York: Taylor and Francis Group. 